\title{
Project Based Learning on Casting of Aluminium Tensile Test Specimen for Mechanical Engineering Students, State Polytechnic of Malang on Odd Semester of Academic Year 2016/2017
}

\author{
S. Hadi ${ }^{1}{ }^{*}$, L. Agustriyana ${ }^{2}$, Subagiyo ${ }^{3}$ \\ ${ }_{1}^{1}$ Mechanical Engineering Department. State Polytechnic of Malang, Indonesia \\ ${ }^{2}$ Mechanical Engineering Department. State Polytechnic of Malang, Indonesia \\ ${ }_{3}^{3}$ Mechanical Engineering Department. State Polytechnic of Malang, Indonesia
}

\begin{abstract}
The problem faced by students is the difficulty of understanding on metal casting topic in the lesson of Materials Technology which is conducted by lectures only. The research objective is to find out the improvement of score on metal casting topic for $1 \mathrm{G}$ students from Mechanical Engineering Department, State Polytechnic of Malang (Polinema) in odd Semester, Academic Year 2016/2017. Research method were facilitation of applied metal casting through pretest of metal casting, added a description of the design and modification of metal mould for Aluminium, visit to a home industry of Aluminium casting, students practice of Aluminium casting in a home industry, student groups presentation and discussion in the subtopics of (1) design and mould manufacture, (2) Aluminium casting practice, and (3) tensile testing with cast Aluminium specimen, as well as posttest on metal casting. The research result is an increasing in average score from 46.56 to 53.6 (22\%) that means by adding the practice to the theory involved is increase a significant impact on understanding of Aluminium casting for students.
\end{abstract}

\author{
Keywords: \\ Mechanical engineering \\ students, \\ Project based learning, \\ Aluminium casting, \\ Tensile test specimen, \\ Home industry of casting
}

\section{Introduction}

Theoretical background which is used was Project Based Learning (PBL)as asystematic learning methode that involved the students in knowledge and skill learning through a structured process of expansionof the investigation around a complex and authentic questionswhich the products and their duties are well designed (Anonymous, 2016). Learning is designed systematically involving input from students in the exploratory capabilities on knowledge previously known.

The object of research is carried out on 3 groups in one classroom with a different task, which means between group members should be able to cooperate, which is expected to improve their learning outcomes as also validated the results of cooperative learning was expressed by Purnamasari (2014) with the results of her research in the form of average scores of independence of learners in cooperative learning Teams Games-Tournament (TGT) acquired high criteria, improved mathematical reasoning skills, and connections better than following the direct learning.

The study participants were 23 students in the $7^{\text {th }}$ semester majored in physical therapy jobs in 2007. In the first cycle is known that the theoretical mastery among students is lacking. It is suggested in the second cycle, students undertake more extensive literature search to expand the theoretical knowledge related to the topics covered had more knowledge of empirical cases, not just theory. In the third cycle indicated that students' skills better in implementing the overall activities of PBL and earned the achievement of course objectives. It can be concluded that PBL is suitable for advanced students prior to the development of a professional, but the mastery of a broader conceptual perspective associated with learning materials is still needed (Kushartanti, 2017).

Results of research was conducted by Lestari (2015) shows that the effort to apply the model of

* Corresponding author.

E-mail Addresses: syampol2003@yahoo.com (S. Hadi), lisa agustriyana@yahoo.com (L. Agustriyana), bagpoltek50@gmail.com (Subagiyo) 
PBL and methods of teaching demonstration is to improve learning outcomes of students of class XI Multimedia 1 SMK Muhammadiyah (private senior high school)Wonosari in the academic year 2014/2015 is the basic competence of the presentation of illustration examples. This can be seen from the improvement of student learning outcomes in each cycle, the first cycle the average percentage of affective learning outcomes worth $68.86 \%$ increased in the second cycle that is worth $83.32 \%$. In the first cycle of psychomotor learning outcomes, the average increase in the individual worth of $62.97 \%$ and the second cycle is $86.85 \%$. Presentation of the group increased psychomotor learning outcomes of the first cycle amounting to $75.66 \%$ and the second cycle is $84.33 \%$. It can be concluded that the application of the model PBL and learning model of demonstration can improve student learning outcomes.

According to the Munawaroh et al. (2012) that results for students with a model of PBL is higher than the cooperative learning model in building four pillars of learning in regular class VIII SMPN (state junior high school)1 Tambakrono in the Academic Year 2011/2012. This is because the four pillars of learning in PBL is more meaningful with aids produced, so that the memory of students to study over a long life (learning to know), PBL is able to motivate the students, so that almost all the students active learning (learning to do), almost all students work in groups with well regardless of cognitive ability and gender (learning to live together), so that consideration of the report of activities with more complete model of PBL (learning to be) compared with cooperative learning.

PBL models in increasing motivation and learning outcomes of students of class XI TOSM I for Competency Skills Motorcycle Engineering SMKN (state senior high school) I Koto XI Tarusan with the number of 20 students. Data were taken through a questionnaire with the help of four observers. Learning outcomes include the areas of cognitive, affective and psychomotor, cognitive areas of learning outcomes was collected using test descriptions while learning outcomes affective and psychomotor fields collected using observational assessment sheets. The findings show that learning in cycle 1 in terms of affective students obtained $73 \%$ rise in the second cycle to $88 \%$ and in terms of psychomotor in cycle 1 worth $60 \%$ increase in the second cycle worth $81 \%$, meaning there is a significant increase learning outcomes after application of learning models of PBL can improve motivation and learning outcomes in minor repairs electrical circuit class XI TOSM 1 on the competence of the automotive engineering expertise Motorcycles SMKN I Koto XI Tarusan (Ganges, 2013).

Opinion of Wardani et al. (2015) on a sample of 42 students at the elementary school of the Laboratory of UPI, Cibiru, District Cileunyi, shows that learning model of PBL compared to conventional learning has value $t$-count $=4.849$ is greater than $t$-table $=0.681$ with a significance value of 0.000 , means of $\mathrm{N}$-gain results show the influence of creative thinking of students increased by a significant category, $0.3<$ $0.63 \leq 0.7$, and conventional learning categorized as low, $0.24 \leq 0.3$, as well as a questionnaire responded positively with the percentage of 100 .

Handayani (2014) states that the results of the study of learning physics with matter a Simple Aircraft against the scientific attitude of 31 students (consisting of 21 women and 10 men) Class VIII-A in SMP Negeri (state junior high school) 8, Muara Jambi in first semester is increasing scientific attitude in each cycle with the average value of the conversion of scientific attitude of students in the first cycle is 2.24 , the second cycle is 2.89 and the third cycle is 3.34. It means that the value of scientific attitude in every cycle already be a good category and has reached the value of minimum completeness criteria (MCC) is $\geq 2.66$ and concluded that the application of PBL models can improve the scientific attitude of students of SMP Negeri 8-Muara Jambi. PBL can provide a positive and beneficial effect greatly to the academic achievement of students (Du, 2016).

\section{Problem}

A problem faced by students is the difficulty of understanding on the topic in the Metal Casting Materials Technology courses during the first semester in the Department of Mechanical Engineering of the state Polytechnic of Malang (Polinema). Lessons are usually given in courses Materials Technology is limited to the level of theory, so most of the students are hard to grasp. The difficulty is trying facilitated by the practice of metal casting by: students working on a pretest for metal casting, adding a description of the design and modification of metal molds for Aluminium, a visit to the home industry in the field of casting for Aluminium, practice for casting an Aluminium by some students at home industry field casting for Aluminium, recording activities, students create activity reports, presentation of reports on activities, discussions, and students working on posttest for metal casting. Presentation by student groups were divided into 3 groups: (1) the design and manufacture of molds, (2) Aluminium casting practice, and (3) the results of tensile testing of Aluminium castings.

A follow-up occurred on observation through a questionnaire on 10 November 2016 to 25 students who carried out the research for Project Based Learning (PBL) in Class 1G in the course of 
materials technology in Mechanical Engineering Study Program of the Department of Mechanical Engineering, Polinema shows that students require a the next action for the improvement of learning from previous ones. Repair or feedback to institutions of learning would improve the quality of learning outcomes for alumni.

Fulfillment for alumni satisfaction is a goal of quality education for Polinema, as well as to meet the educational requirements that have been established in order to meet customer satisfaction.

\section{Plans Troubleshooting}

Plan for solving the problem is to perform the steps as follows: in the early stages pretest students are given the task of answering the questions in the chapter on the metal casting Materials Technology books (ISBN 978-979-29-5586-6) which has been prepared in accordance with curriculum and syllabus of the Department of Mechanical Engineering, Polinema for Semester 1, further provided descriptions of knowledge about metal casting, an answer to a question from the students were discussed in the classroom with the lecturer to check for understanding and improving the understanding of all students regarding a foundry.

Furthermore, prepared a survey to a home industry in the field of casting for Aluminium in Bumiayu-Malang and prepared a set of molds for casting Aluminium as a specimen for tensile test (specimen for tensile tests are required by students of the Department of Mechanical Engineering Polinema for Semester II) for the enrichment of the specimen material as innovation besides just the low carbon steel which for over 30 years has been used continuously, designed a schedule and preparatory visits for students of $1 \mathrm{G}$ Class to come to the casting industry for Aluminum in Bumiayu in the city of Malang during class hours students on Thursday morning, and made an appointment with the owner of the industry so that they prepare everything for the implementation of the casting practice.

The distance between Polinema and Bumiayu is about $10 \mathrm{~km}$ which can be reached by a motorcycle trip around half an hour from campus. In the practice was carried out a demonstration of the preparation of materials and molds, all the equipments needed, melting the metal of aluminum, casting Aluminium materials is being liquefied into a mold, cooling the mold and release castingproduct, finishing the tensile test specimen material for Aluminium, and evaluation the casting process. Students are given the chance to engage fully with the need to comply with and follow all safety procedures by using personal protection equipment (PPE) such as: face shield helmet, safety goggles, leather apron, leather gloves, and safety shoes from leather. Aluminium raw material was obtained from motorcycles pistons scrap with good value expansion coefficient is small value is $<1 \%$ corresponding to tensile test specimens from the test results in the previous casting. In casting practice, students are welcome to record the activities with shooting and making of video on the casting process and the following year can be used as a medium of learning in the classroom with the same subjects, namely metal casting in MaterialsTechnology course. Discussions were held in the next week after the students presented their report on the practice followed by evaluation of all materials, procedures, constraints, student readiness, and quality of Aluminium castings. In the next week,posttest is given to students who have followed the practice of casting.

Raw materials, support equipment, and personal protective equipment should be prepared before the event, Aluminium of piston scrap is purchased as required, the LPG fuel is also prepared in accordance with the needs, knowledge and skills casting techniques and safety work should be given to students before metal casting practice will begin.

\section{Research Objective}

The research objective is to obtain an improvement of learning outcomes on the topic of the foundry for students $1 \mathrm{G}$ class of the Department of Mechanical Engineering, StatePolytechnic of Malang of odd semester in the Academic Year 2016/2017.

\section{Method}

Methodology development and implementation strategies of PBL through a study of 1 Gclass, in the Course of Materials Technology in the first semester focused on the topic of Aluminium foundry in the form of tensile test specimens. The tensile test specimens to be used by them in the practice course of the test material in the second semester, as a continuation of the previous semester. Development of utilizing the tensile test specimens for 30 years was usingonly materials from low carbon steel (St 37) in the forms of cylindrical and rectangular cross-section (without variation of other materials). After the PBL research, 
will be applied practices for testing materials using tensile test specimens of low carbon steelmaterial, Aluminium material, and plasticmaterial(parallel has prepared a mold of steel for producing specimens for tensile test of plastic material).

The implementation strategy immediately followed a study of PBL after the obtained funds to meet the feedback from the questionnaire, provides equipment and materials to the actual foundry practice in a Bumiayu home industry in the city of Malang to introduce and deepen knowledge of Aluminiumfoundry, students assigned to make a report to be presented in the front of the class for the discussions to deepen their understanding. On the other hand there is a student in Semester VI, one among the students are asked to do a final study report is in accordance with the curriculum department of mechanical engineering who conducted early in the beginning of Semester VI to prepare a die cast Aluminium and modify the mold to further treated and was completed in mid-December 2016, which is the right time to be applied in practice for 1Gstudents, who has been through a mid-semester lecture ended in early February 2017. So the chance that they can witness and participate in the preparation of the mold (coaching students a final study report which currently is being Semester V can present to 1Gstudents were currently being Semester I) and the practice of casting specimen for tensile test of Aluminium material.

1GStudentsare also likely to watch the practice on the testing of materials on the topic of Aluminium tensile test specimens were carried out by students who are working on a final study report. The student named Alfiansyah being class 3. All tensile test specimens of materials recycled Aluminium casting results in the first phase were implemented tensile testing to be broken, to obtain data of the tensile force and elongation. Data from the tensile force and elongation is used to plot the stress-strain curve. The rest of the specimen material that has been broken is used as raw material for recycling as tensile test specimens again by re-casting in the second stage. Thus further residual tensile fracture test results followed by a third casting as recycled raw materials in which this activity was appointed as the title of his final report of the study.

\section{Implementation of Castingpractice}

Implementation of the practice of casting through the following steps: starting with the preparation of the mold as Figure 1, smelting Aluminium scrap as Figure 2, pouring molten Aluminium into molds that mold was preheated as Figure 3, Students attending the testing of the Aluminiun tensile test specimensas Figure 4, while Aluminium specimen size and shape as Figure 5, and the presentation and discussion of Aluminium casting as Figure 6.

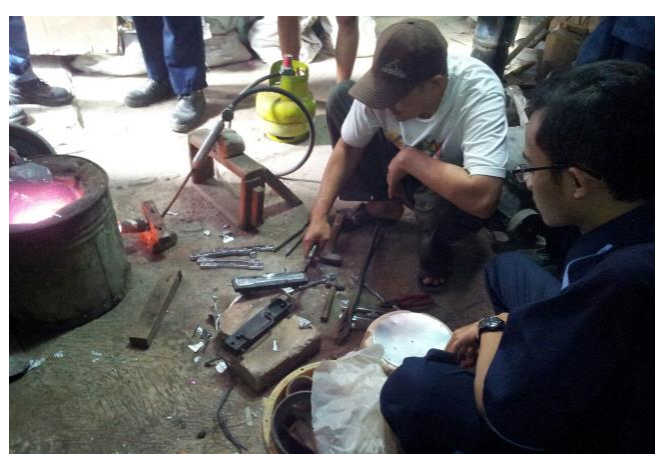

Figure 1. Preparation of the mold for casting specimens of Aluminium material 


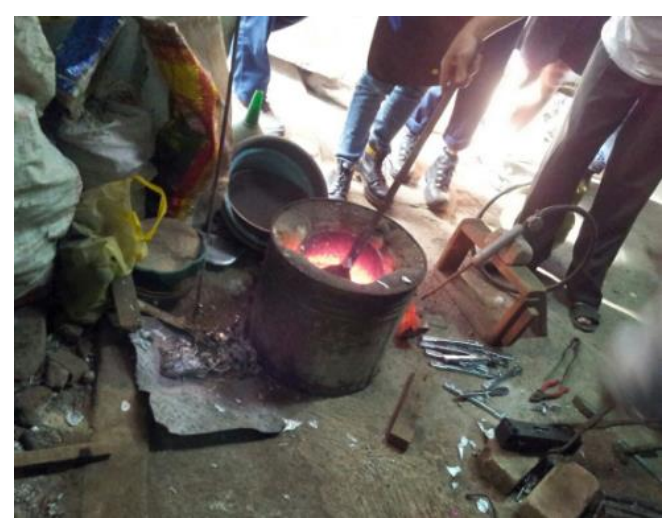

Figure 2. Melting of Aluminium scrap material

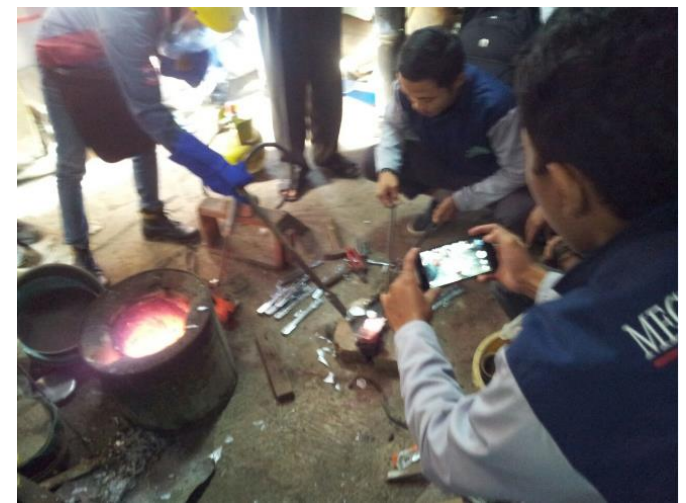

Figure 3. Pouring molten Aluminium into a mold

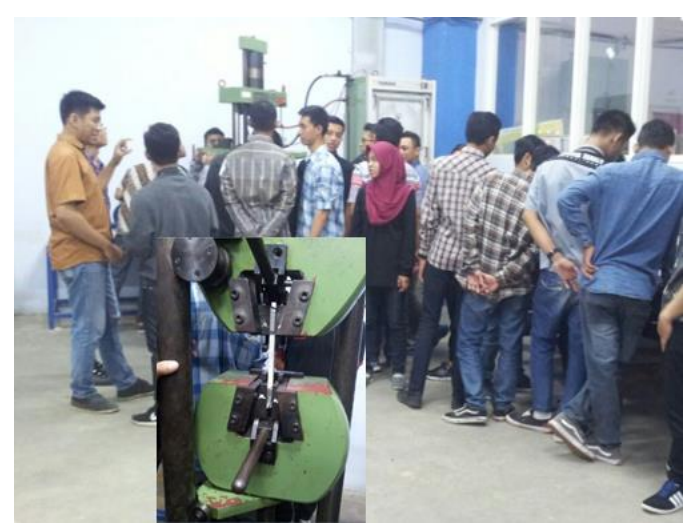

Figure 4.Students attending the testing of the Aluminiun tensile test specimens (inset: holding both end of specimen by the grips of tensile machine) 


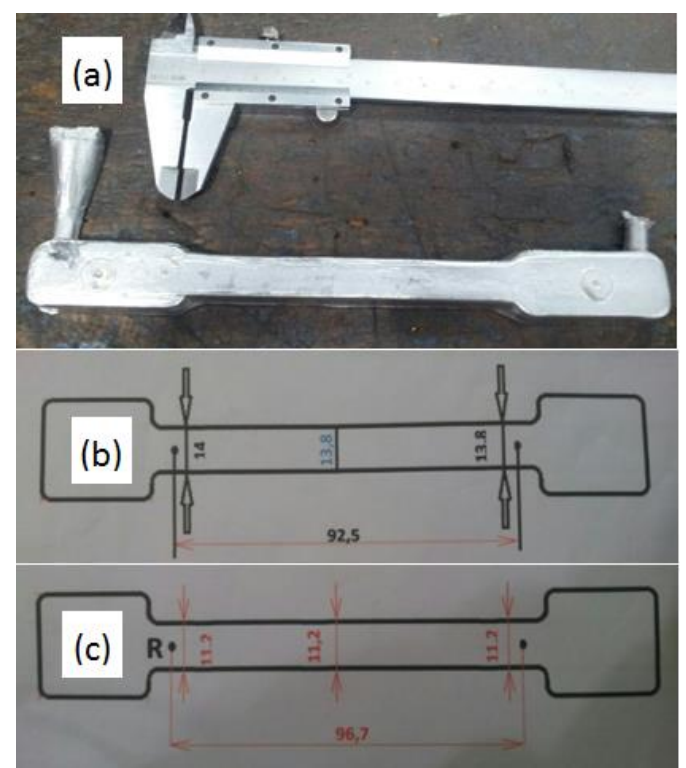

Figure 5. The shape and size of the Aluminiumspecimen

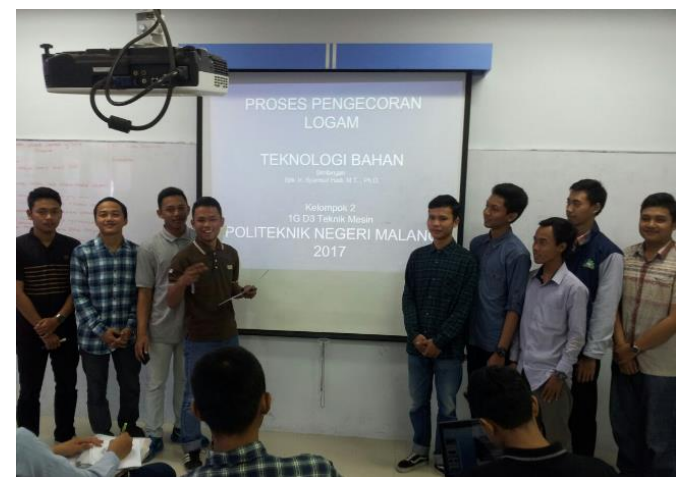

Figure 6. Presentation and discussion in the classroom from $1 \mathrm{G}$ to the topic of Aluminium foundry

\section{Results and Discussion}

PBL activities include the determination of the final result of the ability of the knowledge and skills of students in Aluminiummetal casting.

The ability of the skills and knowledge of students in Aluminium metal casting is the final measurement to be achieved. The existence of students examined through a questionnaire to determine the condition of knowledge, readiness, and constraints, as well as the desired expectations of students. From the results of the questionnaire can be obtained corrective steps in the learning process, in order to obtain perfected.

Assessment of the results of the posttest on students who have followed the practice of casting after the second cycle for 3 weeks as a measure of the success or failure of learning improvement using PBL method. Recapitulation on pretest after the first cycle for 3 weeks, and posttest after the second cycle for 3 weeks along with the percentage progress is shown in Figure 7. 


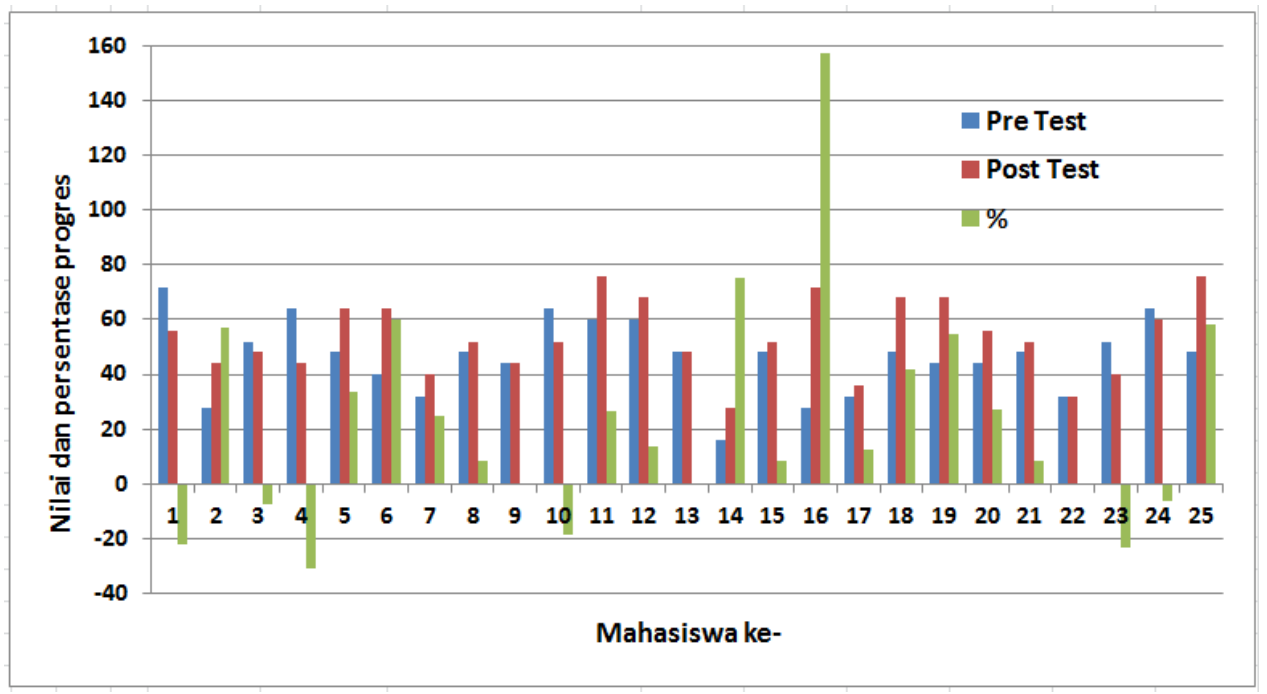

Figure 7. Summary of pretest-posttest and the percentage of progress $1 \mathrm{G}$ to the topic of Aluminiumcasting

In Figure 7 revealed that 17 students experienced an increase in score after the posttest, 3 students did not increase in score, because the scoreof the pretest is equal to the posttest, and 6 students decreased scoreof the pretest to posttest scoresthat can be caused by the kinds of things. There are students who are late when following the practice of casting is only done once at home industry for casting, and not all students have the books of Materials Technology (they are 25 and who has a book just 13), probable they are less diligent to borrow books or internet access, so that their posttest score decreases.

Class average score of pretest was 47 and the results of the posttest score was 54, where learning foundry is further material that is quite difficult which is located in Chapter 7 of 8 chapters contained in the book of the MaterialsTechnology.

The series of knowledge that needs to be understood by students of the first semester include: Chapter 1: mining, processing, and smelting of metal ores, Chapter 2: Structure of Metal Crystals, Sintered Metal and Metal Alloys, Chapter 3: Mechanical properties of metals, Chapter 4: phase diagram and TTT (time-temperature-transformation), Chapter 5: Heat treatment, Chapter 6: Standardization of Metals, Chapter 7: Metal Casting, and Chapter 8: Working for Metal.

Progress development of the increase of the score reaches $22 \%$ of students were considered to be significant for the implementation of PBL for students of the Mechanical Engineering Department Polinema. There are counter-productive for the six students who are impaired in posttest scores, it could be the students less serious possibility that they assume that the foundry is not the practice of mandatory (they can be aware of eight other classes in the same Semester 1, but were not held PBL). The increase, which was reached $24 \%$ in the early stages and if the model is applied more PBL will bring academic armosfir is getting better, presumably should be realized that the vocational education polytechnic models emphasizes the balance between theory and practice that the demands of the future is skilled in the work world.

If the score of the PBL is compared to the score at the end of the $1^{\text {st }}$ semester(semester final score/SFS) for the 1 Gclass, then it can be shown as in Figure 8. 


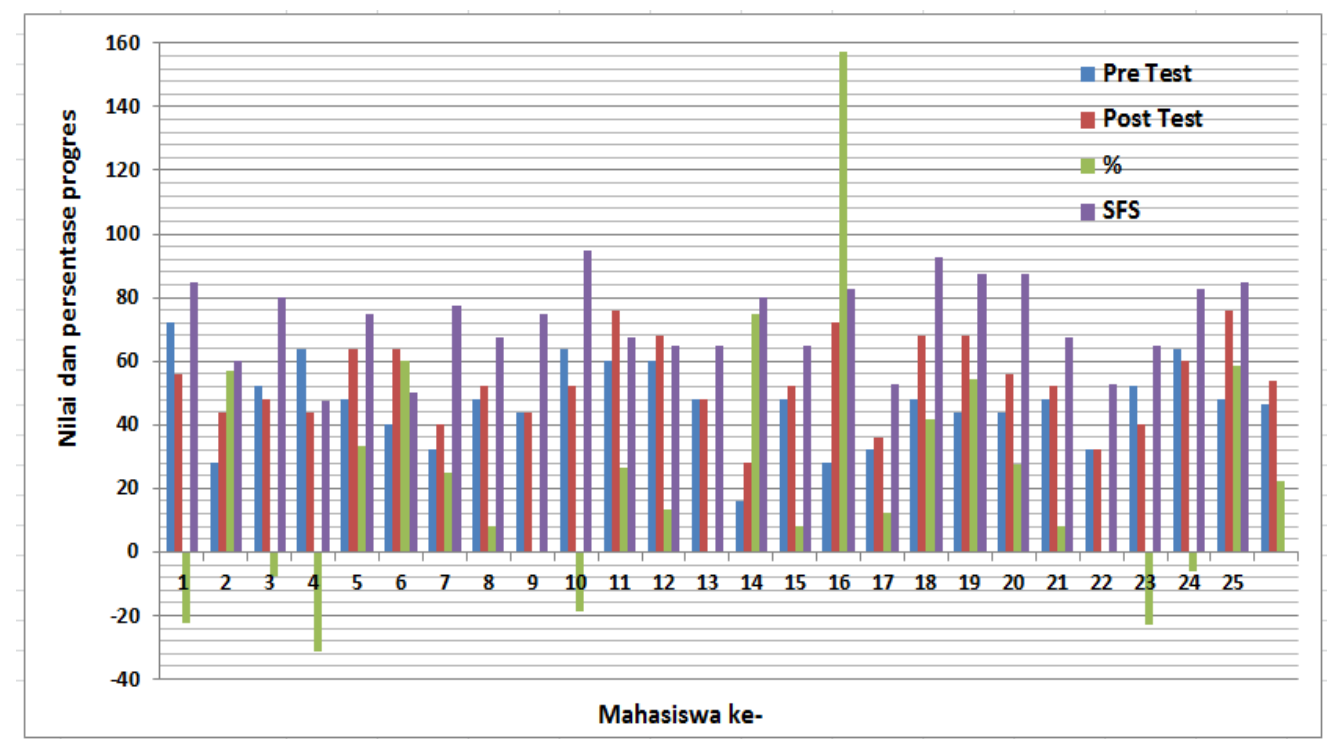

Figure 8. Comparison between Aluminium casting topics scores and scores of the final semester (SFS) for $1 \mathrm{G}$

In Figure 8 the score of the end of the semester (SFS), when compared with the specific score of PBL application with the particular topic of Aluminium casting appears that the scoreof the end of the semester is much higher which represents 8 Chapters in the book of Materials Technology with an average score of the class is 72.

In particular, it is not always there is a correlation between the score of posttest of specific topics Aluminium casting lowers than the pretest was showing the score of the end of the semester is low; it is represented by students at number $1,3,4,10,23$, and 24 . It was shown there is a correlation between the scores of the end of the semester with a score of posttest specific topics from Aluminium casting low anyway to score from the end of the semester is less than 60 for students with numbers 4, 6, 17, and 22, who are academically the four accomplishments below the classaverage. Special student with the number 16 was showing remarkable progress with the $157 \%$ increase of the score from pretest to posttest.

Enthusiasm is high enough shown by 11 students (44\%) experienced an increase in the score of pretest to posttest greater than $25 \%$ of which is the number 1 (57\%), 5 (33\%), 6 (60\%), 7 (25\%), 11 (27\%), 14 (75\%), 16 (157\%), 18 (42\%), 19 (55\%), 20 (27\%), and 25 (58\%).

In general, PBL can enhance student motivation by the enthusiasm reached $44 \%$ and increase the average class score progress is significant, which reached $22 \%$.

\section{Conclusions}

The conclusions that can be drawn from the application of learning models with Project Based Learning (PBL) are: (1) the general method of PBL can enhance student motivation by the enthusiasm reached $44 \%$, and (2) methods of PBL can improve progress with the class average score is significantly reach $22 \%$.

Suggestions follow up the conclusion is the application of PBL model needs careful preparation and well coordinated by the lecturer and the student motivation to the debriefing is preferred for the achievement of optimal results.

\section{Acknowledgement}

Gratitude to the Center for Development and Improvement of Instructional Activities, State Polytechnic of Malang on Teaching Grant to the study entitled Project Based Learning on Casting of Aluminium Tensile Test Specimen for Mechanical Engineering Students, State Polytechnic of Malang on Odd Semester of Academic Year 2016/2017 with letter number 17/PL2.P3AI/TU/2016, dated December $1^{\text {st }}, 2016$, and the willingness of students of 1Gclass, Department of Mechanical Engineering, Polinema. 


\section{References}

Anonim, 2016, Introduction to Project Based Learning, https://www.bie.org/images/uploads/general/20fa7d42c216e2ec171a212e97fd4a9e.pdf, accessed on $17^{\text {th }}$ November 2016.

Ardiyanti, Y. 2016. Berpikir Kritis Siswa dalam Pembelajaran Berbasis Masalah Berbantuan Kunci Determinasi.Jurnal Pendidikan Indonesia.pp. 901-911.

Du, X. M., \& Han, J. 2016.A Literature Review on the Definition and Process of Project-BasedLearning and Other Relative Studies. Creative Education, Volume 7, pp. 10791083.http://dx.doi.org/10.4236/ce.2016.77112

Gangga, A. 2013.Penerapan Model Pembelajaran Project Based Learning dalam Peningkatan Motivasi dan Hasil Belajar.http://download.portalgaruda.org/article.php?article=129165\&val=1482accessed on14th Februari 2017.

Handayani, D.P. 2014. Meningkatkan Sikap Ilmiah Siswa dengan Model Project Based Learning di Kelas VIII A SMP Negeri 8 Muaro Jambi, Jambi. Fakultas Keguruan dan Ilmu Pendidikan, Universitas Jambi.

Kushartanti, BM. Wara. 2017. Pendekatan Problem-Based Learning dalam Pembelajaran Praktek Kerja Lapangan Terapi Fisik. http://staff.uny.ac.id/sites/default/files/131405898/Pendekatan\%20Problem\%20Based\%20Lear ning\%20Dalam\%20Pembelajaran\%20Praktek.pdfaccessed on14th Februari 2017.

Lestari, T. 2015. Peningkatan Hasil Belajar Kompetensi Dasar Menyajikan Contoh-contoh Ilustrasi dengan Model Pembelajaran PBL dan Metode Pembelajaran Demonstrasi bagi Siswa Kelas XI Multimedia SMK Muhammadiyah Wonosari.Skripsi.Yogyakarta.Program Studi Pendidikan Teknik Informatika, Fakultas Teknik, Universitas Negeri Yogyakarta.

Munawaroh, R., Subali, B., dan Sopyan, A. 2012. Penerapan Model PBL dan Kooperatif untuk Membangun Empat Piar Pembelajaran Siswa SMP, Unnes Physics Education Journal, Volume 1 (1), ISSN No. 2257-6935.

Purnamasari, Y. 2014. Pengaruh Model Pembelajaran Kooperatif Tipe Teams Games Tournament (TGT) terhadap Kemandirian Belajar dan Peningkatan Kemampuan Penalaran dan Koneksi Matematik Peserta Didik SMPN 1 Kota Tasikmalaya.Jurnal Pendidikan dan Keguruan, Vol. 1, No. 1, Artikel 2.

Wardani, E. S.; Sutini, A.; Yunansah, H. 2015.Pengaruh Penggunaan Model PBL terhadap Kreativitas Berpikir Siswa pada Konsep Lingkungan.Program Studi Pendidikan Guru Sekolah Dasar, Kampus Cibiru, Universitas Pendidikan Indonesia. 